\title{
Seroprevalence and Molecular Biodiverisity of Hepatitis C Infection in Congolese Diabetics
}

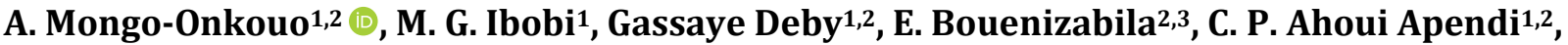 \\ N. Andzouana Mbamognoua 3 , J. F. Mimiesse Monamou ${ }^{1,2}$, A. Boumba ${ }^{2,4}$, \\ N. A. Itoua-Ngaporo ${ }^{1,2}$, B. I. Atipoibara ${ }^{1,2}$, H. G. Monabeka2,3, J.-R. Ibara ${ }^{1,2}$ \\ ${ }^{1}$ Department of Gastroenterology and Internal Medicine, Brazzaville University Hospital Center, Brazzaville, Congo \\ ${ }^{2}$ Faculty of Health Sciences, Ngouabi Marien University, Brazzaville, Congo \\ ${ }^{3}$ Department of Metabolic Diseases of Brazzaville University Hospital Center, Brazzaville, Congo \\ ${ }^{4}$ Laboratory Service Hospital General of Louandjili, Pointe- Noire, Congo \\ Email: mongoonkouo@gmail.com
}

How to cite this paper: Mongo-Onkouo, A., Ibobi, M.G., Deby, G., Bouenizabila, E., Ahoui Apendi, C.P., Andzouana Mbamognoua, N., Mimiesse Monamou, J.F., Boumba, A., Itoua-Ngaporo, N.A., Atipoibara, B.I., Monabeka, H.G. and Ibara, J.-R. (2019) Seroprevalence and Molecular Biodiverisity of Hepatitis C Infection in Congolese Diabetics. Open Journal of Gastroenterology, 9, 22-27.

https://doi.org/10.4236/ojgas.2019.91004

Received: December 22, 2018

Accepted: January 15, 2019

Published: January 18, 2019

Copyright (c) 2019 by author(s) and Scientific Research Publishing Inc. This work is licensed under the Creative Commons Attribution International License (CC BY 4.0).

http://creativecommons.org/licenses/by/4.0/

\section{Open Access}

\begin{abstract}
Summary: There is no evidence for comorbidity diabetes and hepatitis $\mathrm{C}$ virus infection in the Congo. The aim of this work was to determine the seroprevalence and molecular biodiversity of $\mathrm{HCV}$ in order to contribute to improving the management of Congolese diabetics. Patients and methods: It was a cross-sectional study that took place from 1 February to 30 September 2018 at the Brazzaville University Hospital, the Diabcare Health Center and the Adolphe Cissé Hospital in Pointe-Noire. It concerned diabetic patients followed in Brazzaville and Pointe-Noire agreeing to the study, after obtaining the opinion of the ethics committee of the research in health science. All samples collected were screened for the presence of anti HCV Ab using a rapid ALERE HCV test and the Monolisa HCV Ag-Ab ultra test for confirmation in Congo. Detection of the viral RNA was done by PCR retrotranscription and genotyping was performed according to the reverse hybridization technique in France. Data analysis was done with EpiInfo 6.0 software (2016); the proportions were compared using the Chi-square test or the Fisher test at the significance level of 5\%. Results: Of 447 patients with diabetes mellitus, 49 had HCV positive serology and the sex ratio was 0.63 . Seroprevalence of AC anti HCV was 11\% (49/447); HCV RNA was detectable in $71.4 \%(\mathrm{n}=35)$ patients. The average age of the population was $62 \pm 10$ years with extremes ranging from 26 to 82 years. The circulating genotypes were $4(97.1 \%)$ and $1(2.8 \%)$. Subtyping was defined in $17.64 \%(n=6)$ of genotype 4 patients; undefined in $82.36 \%(\mathrm{n}=28)$ of Genotype 4 patients, and in one of genotype 1 patients. The subtypes identified were subtype $4 \mathrm{e}$ $(60 \%)$, subtype $4 \mathrm{e}(8.8 \%)$, subtype $4 \mathrm{a} / 4 \mathrm{c} / 4 \mathrm{~d}(5.8 \%)$, and subtype $4 \mathrm{~h}(2.9 \%)$.
\end{abstract}


Conclusion: The prevalence of HCV is high in our study. These are important data for the improvement of the management of diabetics.

\section{Keywords}

Hepatitis C, Diabete, Congo

\section{Introduction}

Diabetes and hepatitis $\mathrm{C}$ infection are major public health problems worldwide [1] [2]. It is estimated that there are approximately 387 million cases of diabetes in the world. This number can reach 592 million by 2035 and 185 million the number of patients with viral hepatitis C, $80 \%$ of whom are chronic carriers [1] [3] [4]. It is a major cause of morbidity and mortality because it can be complicated by cirrhosis and hepatocellular carcinoma [3] [4]. It is interesting to note that some studies have shown that the prevalence of HCV infection in diabetics is much higher than that of the normal population; others studies have shown that HCV-infected patients tend to develop diabetes, reason attributed to insulin resistance [5]. It is known that diabetic patients are at increased risk of acquiring $\mathrm{HCV}$ due to extensive hospitalization and daily use of syringes [6]. In the Congo, the prevalence of HCV varies between $4 \%$ and $8 \%$ [7] [8] [9]. These results come from several studies carried out on certain populations such as blood donors and polytransfused patients [7] [8]. But no study has been done in diabetics in Congo. The absence of data in the Congo enables us to carry out the present study to determine the seroprevalence of the hepatitis $C$ virus and the molecular profile of HCV in Congolese diabetics in order to contribute to the improvement of the in charge of diabetic patients.

\section{Patients and Methodes}

This was a descriptive and cross-sectional study that took place from 20 February to 28 September 2018, for a period of 6 months. The study was conducted in the Republic of Congo at Brazzaville University Hospital, Diabcare Health Center and Adolphe Cisse Hospital in Pointe-Noire. The choice of health facilities that served as a framework for investigation is justified by the lack of endocrinology service in other cities of the Congo. Indeed, only the cities of Pointe-Noire and Brazzaville have specialized services and well-organized facilities for the management of diabetes allowing the constitution of a representative sample of the population of Congolese diabetics. Serological tests were performed in Brazzaville at the National Public Health Laboratory (LNSP) and molecular analyzes were performed in France at the CERBA Laboratory. Included in our study were all patients at least 18 years old, hospitalized or followed in the various structures mentioned above during the study period and who gave their verbal and/or written consent. The study was conducted after approval of the 
Ethics Committee for Health Research. All patients benefited from a complete clinical examination. The following epidemiological variables were studied: age and sex, occupation, body mass index, risk factors for contamination (blood transfusion, intravenous drug use, history of surgery, scarification, the notion of multiple sexual partners, non-use condoms, tattooing, piercing, accidental needle injury, intravenous drug use. The biological variables were: Ab HCV Ab, HCV RNA, HCV genotype and subtypes, Fibrotest-Actitest. Abdominal ultrasonography was performed in patients with HIV HCV Ab. The search for anti HCV Ac has been done by Elisa (Monolisa HCV Ag-Ab ultra). In the presence of anti-HCV Ab, the molecular study was carried out in France by the CERBA laboratory. Quantitation of RNA was done by PCR (Cobas ${ }^{\circledast}$ 6800/8800 Roche Systems), the molecular genotyping was done by reverse hybridization (INNO-LIPA HCV 2.0, Innogenetics/Bayer HC). he data analysis was done with the Epi Info $6.0 \mathrm{~V} 7$ software. The proportions were compared using the Chi-square test or the Fisher test at the significance level of 5\%.

\section{Results}

In total, 447 patients were incluted in the study during 6 months. The mean age was $58 \pm 12$ years with extremes ranging from 23 to 88 years, the majority of patients were $\geq 60$ years of age or $50.1 \%(n=224)$, patients aged between $50-59$ years were $124(27.7 \%)$, those between 40 - 49 years old were 65 (14.7\%), those aged 30 - 39 were $30(6.7 \%)$, those under 30 years old were $30(6.7 \%)$ These were $59 \%(\mathrm{n}=265)$ of female patients and $41 \%(\mathrm{n}=181)$ of male patients. The sex ratio was 0.68 . There were $60 \%(\mathrm{n}=268)$ of patients with type 2 diabetes, $40 \%(\mathrm{n}=$ 179) of patients with type 1 diabetes. Seroprevalence of antiVHC Ab was $11 \%$ (49/447) (Table 1). The average age of HCV-positive patients was $62 \pm 10$ years with extremes ranging from 26 to 82 years. Of the 49 patients with anti HCV Ab, $61.2 \%(30 / 49)$ were female and $38.8 \%(19 / 49)$ were male. The sex ratio $(\mathrm{m} / \mathrm{f})$ was 0.63 . Patients over 50 were most affected by hepatitis $\mathrm{C}$ but there was no statistically significant relationship $(\mathrm{p}=0.001)$. Table 2 illustrates the comparison between the age group and the positivity of anti-HCV Ab. The most common risk factor for contamination was scarificationin $49 \%(\mathrm{n}=24)$, follow-up of multiple sexual partners $36 \%(\mathrm{n}=18)$, blood transfusion in $10.2 \%$ $(n=5)$, surgery and non-use of presevative in $2 \%$ each. The polyuro-polydypsic syndrome was found in $47 \%(\mathrm{n}=23)$ patients. The signs of chronic liver disease (jaundice: $8.2 \%$, ascites: $8.2 \%$ ) were found at the time of diagnosis. Across our sample, $45 \%$ (22/49) were overweight and 39\% (19/49) were obese. Of the HCV-positive patients, 71.4\% (35/49) had detectable viral loads. After viral sequencing, genotype 4 (G4) was identified 4 in $97.1 \%(n=34)$, genotype 1 (G1) in one patient, $8 \%(\mathrm{n}=1)$. Subtyping was possible in $17.64 \%(\mathrm{n}=6)$ of patients, $8.8 \%(\mathrm{n}=3)$ of patients had subtype $4 \mathrm{e}$ and subtype $4 \mathrm{~h}$ in $2.9 \%(\mathrm{n}=1)$ patients. Genotyping and subtype results are shown in Table 3 . There was no link between genotype and type of diabetes $(p>0.05)$. Table 4 represents the comparison between genotype and the type of diabetes. 
Table 1. Distribution of HCV positive patients by age group.

\begin{tabular}{ccc}
\hline Age range & $\mathrm{n}$ & $\%$ \\
\hline$<30$ ans & 1 & 2.0 \\
$40-49$ ans & 1 & 2.0 \\
$50-59$ ans & 19 & 38.8 \\
$\geq 60$ ans & 28 & 57.2 \\
Total & 49 & 100.0 \\
\hline
\end{tabular}

Table 2. Comparison between HCV positive antibody patients and age group.

\begin{tabular}{|c|c|c|c|c|}
\hline \multirow{2}{*}{ Age range } & Ac anti VHC & \multirow{2}{*}{ OR } & \multirow{2}{*}{ IC 95\% } & \multirow[b]{2}{*}{$\mathrm{p}$} \\
\hline & positive & & & \\
\hline$<50$ ans & $2(4.1 \%)$ & 0.13 & $0.031-0.554$ & 0.001 \\
\hline$\geq 50$ ans & 47 (95.9\%) & 1.26 & $1.17-1.37$ & 0.001 \\
\hline
\end{tabular}

Table 3. Distribution of patients by genotype and subtype.

\begin{tabular}{cccc}
\hline Genotype & $\mathrm{n}(\%)$ & Subtype & $\mathrm{n}(\%)$ \\
\hline 1 & $1(2.86)$ & undefinited & $1(100.0)$ \\
& & undefinited & $28(82.36)$ \\
4 & $34(97.14)$ & $4 \mathrm{a} / 4 \mathrm{c} / 4 \mathrm{~d}$ & $2(5.88)$ \\
& & $4 \mathrm{e}$ & $3(8.82)$ \\
& & $4 \mathrm{~h}$ & $1(2.94)$ \\
\hline
\end{tabular}

Table 4. Comparison between genotype and type of diabetes.

\begin{tabular}{|c|c|c|c|c|c|}
\hline \multirow{2}{*}{ Type } & \multicolumn{2}{|c|}{ Genotype } & \multirow{2}{*}{ OR } & \multirow{2}{*}{ IC 95\% } & \multirow{2}{*}{$\mathrm{p}$} \\
\hline & Génotype 1 & Génotype 4 & & & \\
\hline Diabète 1 & $1(100 \%)$ & $3(8.82 \%)$ & 1.05 & $0.9-1.1$ & $>0.05$ \\
\hline Diabète 2 & $0(0.0 \%)$ & $31(91.18 \%)$ & 0,94 & $0.84-1.05$ & $>0.05$ \\
\hline
\end{tabular}

\section{Discussion}

The seroprevalence of anti-HCV Ab in our study population is high (11\%). The results of our study are identical to those found in the world by other authors [4] [10] [11]. This high prevalence among diabetics is explained by the absence of a policy for the prevention and control of viral hepatitis $\mathrm{C}$ in Congo. Indeed, despite progress in prevention, control and care, the Congo does not always have a program to fight against viral hepatitis. Laloo et al. reported lower prevalence among diabetics [5]. Elira-Dockekias et al. reported 13.6\% $(\mathrm{n}=35)$ in sickle cell patients [8]. However, Atipo-Ibara et al. found $4.6 \%$ in blood donors [7]. The difference can be explained by the loyalty efforts of regular and occasional blood donors. This supports the hypothesis that regular blood donors are at low risk of transmission through blood transfusion, to the extent that they receive information about the importance of transfusion safety and are followed up by regular screening at each blood donation [7]. HCV RNA was detected in 35 out 
of $49 \mathrm{HCV}$-positive patients, with a molecular prevalence of $71.4 \%$. Diarra et al. in Mali reported a molecular prevalence of 92\% [4]. This high prevalence of patients with chronic HCV infection may be due to delayed diagnosis and/or lack of early management of the disease.Indeed, before our investigation, no diabetic patient knew his viral status. We identified genotype 4 in $10.7 \%$ of patients and genotype 1 in $0.2 \%$ of patients. The preponderance of Genotype 4 in our series is due to its endemic nature in Central Africa. Indeed, the epicenter of genotype 4 is located in Central Africa [12] [13] [14]. Several studies carried out in Congo corroborate our results although they are different populations [8] [13]. Genotype 1 is not common in Congo, its presence in our series could be explained by the immigration of Western populations, West Africans and Magrebine in Congo. Kabbaj et al. in Morocco reported a predominance of genotype $1(60.4 \%)$ and genotype $2(39.6 \%)$. However, genotypes 3 and 4 were not found in their study [15]. The difference between our studies is explained by the phileogeography of HCV in the world [16]. In our study, subtype 4e was predominant $61.4 \%$, followed by subtype $4 \mathrm{~h}(2.9 \%)$. However, our data are identical to those reported by Mongo-Onkouo et al. [13]. In addition to patients with genotype 4 and 1, the subtype could not be clearly identified in 4 cases. The difficulty of subtype determination by the INNO LIPA method has been noted by several authors [5] [12].

Our study has some limitations including the non-systematic realization of the load in all patients because a negative HCV serology does not exclude the carriage of HCV RNA. Thus, PCR remains the best diagnostic tool for HCV infection because the detection of HCV RNA is the only control viral replication. Similarly, the size of our sample is small, it does not allow us to extrapolate our results on the national diabetic population.

\section{Conclusion}

At the end of our study, the prevalence of HCV is high among diabetics. This rise in prevalence highlights the importance of HCV testing in Congolese diabetic patients. The establishment of a program to fight against viral hepatitis will reduce the morbidity of this infection as well as these complications in the Congolese population.

\section{Conflicts of Interest}

The authors declare no conflicts of interest regarding the publication of this paper.

\section{References}

[1] Ba-Essa, E.M., Mobarak, E.I. and Al-Daghri, N.M. (2016) Hepatitis C Virus Infection among Patients with Diabetes Mellitus in Dammam, Saudi Arabia. BMC Health Services Research, 16, 313. https://doi.org/10.1186/s12913-016-1578-0

[2] Knobler, H. and Schattner, A. (2005) TNF- $\alpha$, Chronic Hepatitis C and Diabetes: A Novel Triad. Physicians, 98, 1-6 
[3] Lemoine, M., Eholié, S. and Lacombe, K. (2015) Reducing Neglected Burden of Viral Hepatitis in Africa: Stratégies of the Global Approach. Journal of Hepatology, 62, 469-476. https://doi.org/10.1016/j.jhep.2014.10.008

[4] Diarra, M.T., Konate, A., Diakite, Y., et al. (2013) Infection with Hepatitis C Virus in Diabetic Patients Treated at the Gabriel Touré Teaching Hospital and at the Bamako Diabetes Center (Mali). Journal Africain d Hépato-Gastroentérologie, 7, 188-191. https://doi.org/10.1007/s12157-013-0487-7

[5] Laloo, D., Walke, P., Bhimo, T., Prasad, L. and Ranabir, S. (2015) Seroprevalence of Hepatitis C Infection in Type 2 Diabetes Mellitus. Indian Journal of Endocrinology and Metabolism, 19, 296-299. https://doi.org/10.4103/2230-8210.149325

[6] Masson, A.L., Lau, J.Y.N., Hoang, N., et al. (1999) Association of Diabete Mellitus and Chronic C Virus Infection. Hepatology, 29, 228-333.

https://doi.org/10.1002/hep.510290235

[7] Atipo-Ibara, B.I., Mimiesse, J., et al. (2014) Hepatitis C Virus: Study of Genotypes in Congo Brazzaville. Journal Africain d Hépato-Gastroentérologie, 8, 16-19. https://doi.org/10.1007/s12157-014-0506-3

[8] Elira-Dokekias, A., Okandze-Elenga, J.P., Gouary Kikouna, S., Dzia-Lepfoundzou, A. and Garcia, S. (2003) Seroprevalence of Viral Hepatitis C in Polytransfused Patients at the CHU of Brazzaville. Bulletin de la Société de Pathologie Exotique, 96, 279-282.

[9] Ahoui Apendi, C., Bossali, F., Ibara Atipo, B.I., et al. (2016) Treatment of Viral Hepatitis C at the University Hospital of Brazzaville in 2015. Annals of Marien Ngouabi University, 16, 27-31

[10] Ndako, J.A., Echeonwu, G.O., Shidali, N.N., et al. (2009) Occurrence of Hepatitis C Virus Infection in Type 2 Diabetic Patients Attending Plateau State Specialis Hospital Jos Nigeria. Virology Journal, 6, 1-5.

[11] Jadoon, N.A., Shahzad, M.A., Yaqoob, R., Hussain, M. and Ali, N. (2010) Seroprevalence of Hepatitis C in Type 2 Diabetes: Evidence for a Positive Association. Virology Journal, 7, 304. https://doi.org/10.1186/1743-422X-7-304

[12] Ntagirabiri, R., Poveda, J.D., Mumana, A. and Ndayishimiye, H. (2014) Genotypes and Subtypes of Hepatitis C Virus in Burund: A Particularity in Sub-Saharan Africa. Pan African Medical Journal, 19, 69.

[13] Mongo-Onkouo, A., Ahoui Apendi, C.P. and Mimiesse Monamou, J.F. (2018) Distribution of Genotypes and Sub Types of Hepatitis C Virus in Congo-Brazzaville. Health Science, 19, 33-36.

[14] Ntagirabiri, R., Baransaka, E., Ndayiragije, A. and Niyongabo, T. (2014) Prevalence of Hepatitis C Virus in Burundi: National Survey. Journal Africain d HépatoGastroentérologie, 8, 25-28. https://doi.org/10.1007/s12157-014-0511-6

[15] Kabbaj, N., Errabih, I., Ghedira, M., et al. (2006) Viral Hepatitis C and Diabetes: Influence of Diabetes on the Course of Hepatopathy. Annales d Endocrinologie, 67, 233-237. https://doi.org/10.1016/S0003-4266(06)72591-4

[16] Ilesa, J.C., Raghwania, J., Harrison, G.L.A., Pépin, J., Djoko, C.F., Tamoufee, U., et al. (2014) Phylogeography and Epidemic History of Hepatitis C Virus Génotype 4 in Africa. Virology, 464-465, 233-243. https://doi.org/10.1016/j.virol.2014.07.006 